\title{
The Traitor in Nuno Treez 2
}

\author{
RIP COHEN
}

\begin{abstract}
The traitor (traedor) against whom a girl vows vengeance in a cantiga d'amigo of Nuno Treez (presumably a thirteenth century Galician jograr) might be thought to be San Clemenço, to whom the text is addressed, but an examination of pragmatic criteria supports the argument that the traitor is the girl's boyfriend, who may merely be late in returning to her.
\end{abstract}

Keywords: Galician-Portuguese lyric, cantigas d'amigo, Nuno Treez, literary pragmatics, amorous betrayal and vengeance.

IN NEARLY every cantiga d'amigo there is at least one problem of interpretation. Sometimes it stares us in the face. Sometimes it takes some looking. And in a mere suggestion made by a top scholar there may lurk a lingering doubt, even if that suggestion has not taken hold ${ }^{1}$. Carolina Michaëlis, in an apparently off-hand comment on Nuno Treez 2, wonders if the «false traitor» in this text is the girl's boyfriend or San Clemenço.

Data de recepción: 07-11-2017 - Data de aceptación: 13-07-2018.

Nuno Treez 2 is analyzed in Cohen (1996: 8-9), but there I do not even consider the problem addressed here, since I saw no problem. Nunes (1926-1928: I, 236) assumes without explanation that the girl swears vengeance against the boy. Other scholars (for example, Couceiro 1993: 485) agree, again without explaining their reasoning. The text and numbering of the cantigas d'amigo are taken from Cohen (2003). The translations are mine. 
NUNO TREEZ - 2

aaB (x3): $6 \| 4$

ar or or $\|$ ei

San Clemenço do mar, se mi del non vingar, non dormirei.

San Clemenço senhor, se vingada non for,

non dormirei.

Se vingada non for do fals' e traedor, non dormirei.

$B 1201$ f. $255 \mathrm{r} \quad V 806$ f. $126 \mathrm{v}$

$\mathbf{1}$ clemenco $B$ : cremenço $V$ mar] mal $V \mathbf{4}$ clemẽco $B$ : demenço $V \mathbf{8}$ craedor $V \mathbf{9}$ dormirey $V:$ om. B

San Clemenço of the Sea,

If I don't get back at him

I will not sleep.

San Clemenço, lord,

If I don't take revenge

I will not sleep.

If I don't take revenge

Against that lying traitor

I will not sleep.

Michaëlis (CA II: 889) says that the girl, feeling wronged, swears vengeance, but suggests that the lass herself is not sure if she means to get back at the boy or the saint («Despeitada jura vingar-se, nem ella sabe bem se do amante ou do intermediário»).

This question could be treated as grammatical: Is San Clemenço do Mar a vocative or does it anticipate $e l$ in the second verse? Such a prolepsis is possible. Consider Pero Meogo 1.1-2 (Cohen 2014: 18): O meu amig', a que preito talhei, / con vosso medo, madre, mentir lh' ei («For fear of you, mother, I'll break my word to my friend, with 
whom I made a pact»). In that text o meu amigo anticipates the indirect object of mentir, the pronoun $l h$ ' in the second verse. Another example occurs in Johan Soarez Coelho 4.1-2 Ai madr,'o que eu quero ben / non lh'ous'eu ante vós falar («Oh mother, the one I love-I don't dare to speak to him in front of you») and yet another in Vaasco Perez Pardal 3.1-2 provad'un dia / o voss'amigo de vo-lh'assanhar («Try sometime getting angry at your boyfriend»). In the corpus of 501 cantigas d'amigo the whole first verse constitutes a prolepsis in two texts:

Pero Gonçalvez do Porto Carreiro 3 O anel do meu amigo / perdi-o so-lo verde pino Johan Zorro 5 Cabelos, los meus cabelos / el rei me enviou por elos

Texts where the incipit consists solely of a vocative are more numerous²:

Afons'Eanes do Coton 1 Ai meu amig'e meu lum'e meu ben

Pae Gomez Charinho 6 Ai Santiago, padron sabido

Martin Codax 1 Ondas do mar de Vigo

Martin de Giinzo 5 Ai vertudes de Santa Cecilia

Dinis 16 Aiflores, ai flores do verde pino

Dinis 18 Amig'e meu amigo

Dinis 31 Amig'e fals' e desleal

Dinis 40 Ma madre velida

But in the second strophe of Nuno Treez 2 there is no following pronoun (in II.2) to which an alleged prolepsis (in II.1) could refer. At any rate, the question cannot be decided merely by analyzing syntax. We need, above all, to understand the action. As far as I can tell, the only pragmatic evidence in the cantigas d'amigo that can be adduced to support the assumption that the opening verse in Treez 2 is proleptic (and therefore the girl calls the saint a traitor) and not vocative (in which case the traitor is the boy) is another text by the same poet, where the girl is upset with the saint because he has not brought the boy to her, even though she pleads with him to do so.

NUNO TREEZ - 3

$$
\begin{aligned}
& \text { aaB }(\mathrm{I}-\mathrm{IV})>\mathbf{a a B}(\mathrm{V}-\mathrm{VI}): 16 / 15^{\prime}\left[7^{\prime}+8 / 7^{\prime}\right] \| \\
& \text { on } \mathrm{i} / \mathrm{in} \text { ar } 5^{\prime}\left[7^{\prime}+7\right] \\
& \text { or (ade) is (igo) ia } \| \text { (igo) igo }
\end{aligned}
$$

\footnotetext{
2 In two texts the opening vocative occupies the first two verses: Martin de Caldas 5 Ai meu amig'e lume destes meus / olhos, e coita do meu coraçon; Pero Gonçalvez do Porto Carreiro 1 Ai meu amigo e meu senhor / e lume destes olhos meus.
} 
Non vou eu a San Clemenço | orar, e faço gran razon, ca el non mi tolhe_a coita $\mid$ que trago no meu coraçon, nen mh aduz o meu amigo, | pero lho rog' e lho digo.

Non vou eu a San Clemenço, | nen el non se nembra de min, nen mh aduz o meu amigo, | que sempr' amei des que o vi,

nen mh aduz o meu amigo, | pero lho rog' e lho digo.

Ca se $\mathrm{el}<\mathrm{e}>\mathrm{m}$ ' adussesse $\mid$ o que me faz pẽad' andar, nunca tantos estadaes $\mid$ arderan ant' o seu altar,

nen mh aduz o meu amigo, | pero lho rog' e lho digo.

Ca se el $<\mathrm{e}>\mathrm{m}$ ' adussesse $\mid$ o por que eu moiro d' amor,

nunca tantos estadaes | arderan ant' o meu senhor,

nen mh aduz o meu amigo, | pero lho rog' e lho digo.

Pois eu $\mathrm{e}<\mathrm{n}>$ mha voontade $\mid$ de o non veer son ben fis, que porrei par caridade | ant' el candeas de Paris?

nen mh aduz o meu amigo, | pero lho rog' e lho digo.

En mi tolher meu amigo | filhou comigo perfia, por end' arderá, vos digo, | ant' el lume de bogia, nen mh aduz o meu amigo, | pero lho rog' e lho digo.

$B 1202$ f. $255 \mathrm{r} \quad V 807$ ff. $126 \mathrm{v}-127 \mathrm{r}$

I'm not going to San Clemenço to pray, and it's only right, Since he doesn't take away the yearning that I feel in my heart, And he doesn't bring me my boyfriend, though I ask him, though I plead.

I'm not going to San Clemenço, nor does he remember me, Nor does he bring me my boyfriend, whom I've always loved, since first sight, And he doesn't bring me my boyfriend, though I ask him, though I plead.

'Cause if he brought me the one who makes me go around yearning

Never would so many candles have burned before his altar;

And he doesn't bring me my boyfriend, though I ask him, though I plead.

'Cause if he brought me the one for whom I'm dying of love

Never would so many candles have burned before my lord;

And he doesn't bring me my boyfriend, though I ask him, though I plead. 
Since in my heart I am certain that I won't see my boy,

Why should I put Parisian candles before him, for goodness' sake?

And he doesn't bring me my boyfriend, though I ask him, though I plead.

By taking my boyfriend away from me, he really picked a fight,

And so what will burn before him, I'm telling you, will be cheap wax,

And he doesn't bring me my boyfriend, though I ask him, though I plead.

The girl is so distraught by the saint's failure to grant her prayer that she will no longer bother praying to him (I.1, II.1). She has given up hope (V.1) and claims that the saint has «picked a fight» with her by depriving her of her boyfriend (VI.1). This text seems to be the only reason why the identity of the traitor in Nuno Treez 2 might appear problematic.

I believe (and shall argue here) that this potential problem disappears if we check the text against the pragmatic grammar of the genre (Cohen 2010). Does the girl want to take vengeance on the boy - for whatever reason - or does she want to get back at San Clemenço? Which of these interpretations better fits poetic praxis in the cantigas d'amigo?

This poem contains an oath: «Until I take revenge, I shall not sleep». Historically, an oath is a promise or affirmation conditioned on a curse invoked against oneself. The formula of an oath is intended to guarantee the truth of the speaker's affirmation or her intention to fulfill a promise. The person who swears an oath calls down upon herself a curse if she does not do what she swears. In this case, the girl swears that she will get back at $X$; and if she does not, she will forgo sleep. But despite Treez 3, where the girl says the saint has not delivered the boy to her, the saint can hardly have sworn or promised to do anything. There is no contractual relationship between the saint and the girl (such as there is in the covenant between God and the Israelites in the Hebrew Bible). And nowhere in the cantigas d'amigo does a girl call a saint falso or traedor ${ }^{3}$. She uses these adjectives (and the corresponding nouns traiçon and

Nonetheless, see $C A$ II: 874: «Fiel aos exemplos tradicionaes, o povo de hoje continua na firme persuasão, a que já alludi, que mesmo os santos são amigos de folias. Por isso festeja-os com acclamações e provocações e troça-os de mil modos, promettendo-lhes coisas bonitas, e ameaçando-os de castigos, se não ouvirem as suas orações, nem agradecerem a rude ingenuidade dos seus holocaustos e das suas homenagens». More information is provided in the note (CA II: 874n4): «As raparigas do campo, e também os pescadores e outros artistas analphabetos, batem os seus santinhos, põe-nos de mergulho num copo de agua ou num poço, partem-nos em pedaços, ou enforcam-nos, se não cumprem os seus desejos. - Cfr. Ord. Man. V, p. 33, 3: "Outros levam as imagens de alguns santos acerca d' agua e ali fingem que os querem lançar em ella, e tomam fiadores que se até certo tempo o dito Santo lhes nom der agoa, ou outra cousa que pedem, que lançaram a dita imagem na agua"». 
falsidade) only of the boy. This is because fala, the relationship between a girl and a boy, is contractual (Cohen 2012: 10). Any promises that have been made must be kept. So to swear (jurar, põer, fazer preito) is no light matter. To break an oath or fail to keep one's word (mentir) is a breach of trust that often causes anger - and entitles the other party to break off the relationship and to take revenge.

When the girl gets angry at the boy, she may insult him (Cohen 1996: 5-16). When she does so, she uses a small lexicon, including the verb mentir, the adjectives falso and perjurado, and the noun traedor. Here are examples from other aaB cantigas d'amigo.

e mentiu m'e tort'á feito («and he broke his word and did me wrong») Pae Soarez de Taveirós 3 mentiu mh o meu amigo («my boyfriend broke his word to me») Pero Garcia Burgalês 1 mentistes mi, ai perjurado («you broke your word to me, you liar») Pero Garcia Burgalês 2 por que mentiu o perjurado? («why did the liar break his word?») Dinis 14 aquel que mentiu do que pos con migo («who broke his word about his promise to me») Dinis 16

The girl can also swear to take revenge (see below). But why would the girl in Treez 2 call the boy traedor or say that he is false and vow revenge? Elsewhere a girl calls a boy a traitor simply for not showing up, as in these two texts.

\section{AFONSO LOPEZ DE BAIAN - 1.13-18}

Fui eu rogar muit' a Nostro Senhor non por mha alma,_<e>candeas queimei, mais por veer o que eu muit' amei

sempr', e non vẽo o meu traedor:

gran dereit' é de lazerar por en, pois el non vẽo, nen aver meu ben.

I went to really beg Our Lord,

And to light candles, not for my soul,

But to see the boy I've always loved

So much, and the traitor didn't come;

Since he didn't come, it's only right

That he suffer and get no favors from me.

MARTIN DE GIINZO - 6

Non mi digades, madre, mal e irei vee-lo sen verdad' e que namorei

na ermida do Soveral 
u m' el fez muitas vezes coitada estar, na ermida do Soveral.

Non mi digades, madre, mal, se eu for vee-lo sen verdad' e o mentidor

na ermida do Soveral

u m' el fez muitas vezes coitada estar, na ermida do Soveral.

Se el non ven i, madre, sei que farei:

el será sen verdad' e eu morrerei

na ermida do Soveral

u m' el fez muitas vezes coitada estar, na ermida do Soveral.

Rog' eu Santa Cecilia e Nostro Senhor que ach' oj' eu i, madr', o meu traedor na ermida do Soveral u m' el fez muitas vezes coitada estar, na ermida do Soveral.

Don't speak ill of me, mother, and I'll go

To see the faithless boy with whom I fell in love

In the chapel of Soveral

Where he so often made me sad

In the chapel of Soveral.

Don't speak ill of me, mother, if I go

To see the faithless boy who lied to me

In the chapel of Soveral

Where he so often made me sad

In the chapel of Soveral.

If he doesn't come, mother, I know what I'll do:

He'll prove faithless, and I'll just die

In the chapel of Soveral

Where he so often made me sad

In the chapel of Soveral.

I pray to Santa Cecilia and to Our Lord

That I find there, mother, my traitor-boy

In the chapel of Soveral 
Where he so often made me sad

In the chapel of Soveral.

And even being late is an act of betrayal in Pero da Ponte 3.15-16 por que mi tarda e non ven / faz sobre mi gran traiçon («Since he lingers and doesn't come, he is committing high treason against me»). The boy's intention to go away, against the girl's will, is also deemed treachery.

DINIS - 51.6-10

Defendi lh' eu que se non fosse daqui, ca todo meu ben perderia per i, e ora vai s' e faz mi gran traiçon, e des oi mais non sei que seja de min nen $<$ ar $>$ vej' i, amiga, se morte non. 10

I forbade him to go away from here,

'Cause he'd lose all my favors that way,

And now he's going, and he's betraying me,

And from now on I don't know what I'll do,

And I can't see anything out there but death.

If the boy loves another girl, he is naturally a traitor.

FERNAN VELHO - 1.1-8

Vedes, amigo, $<_{0}>$ que oj' oí

dizer de vós, assi Deus mi perdon, que amades ja outra e mi non, mais, se verdad' é, vingar m' ei assi:

punharei ja de vos non querer ben;

e pesar mh á én mais que outra ren

Oí dizer por me fazer pesar

amades vós outra, meu traedor,

Listen, friend, to what I heard today

Said about you, so help me God:

That you love another and not me;

And if it's true, I'll get revenge this way:

I'll try not to love you, beginning now,

And it'll hurt me more than anything. 
I heard it said that, just to cause me pain,

You love another, my treacherous friend

The girl uses falso in similar situations ${ }^{4}$. For example, when the boy has another girl he easily merits the adjective.

AFONSO MEENDEZ DE BEESTEIROS - 1.1-4

Fals' amigo, per bõa fe,

m' eu sei que queredes gran ben

outra molher, e por mi ren

non dades

False friend, in good faith,

I know you are in love

With another woman, and don't care

About me at all

The girl calls the boy falso if he has sworn that he loves her and promised to come to see her but then does not appear for a tryst.

PERO DE BERDIA - 2

Jurava mh o meu amigo, quand' el falava comigo, que nunc' alhur viveria

sen mi, e non mi queria

tan gran ben como dizia.

Foi un dia polo veer

a Santa Marta, e mãer

u m' el jurou que morria

por mi, mais non mi queria

tan gran ben como dizia.

10

Se m' el desejasse tanto

como dizia, logo ant' o

4 In addition to the examples cited, see Juião Bolseiro 6.9, 13 (he has another girl); Juião Bolseiro $8.4,7,9,15$ (he boasted about the girl); and Dinis 43.1, 7, 13 (he apparently used the girl as a screen to cover up a relationship with another girl). 
tempo que disse verria,

mais sei que mi non queria

tan gran ben como dizia.

Pod' el tardar quanto quiser, mais, por jurar quando vẽer, ja volh' eu non creeria, ca sei que mi non queria tan gran ben como dizia.

Ai fals', e por que mentia quando mi ben non queria?

My friend used to swear to me When he was talking with me That he'd never live elsewhere Without me, and he didn't love Me as much as he said.

I went one day to see him

At Santa Marta and spend the night

Where he swore he was dying

For me, but he didn't love

Me as much as he said.

If he desired me as much

As he said, then he'd come

Before the time he said,

But I know that he didn't love

Me as much as he said.

He can linger there all he likes

But though he swear when he comes back

I won't believe him any more,

'Cause I know that he didn't love

Me as much as he said.

Liar! And why did he lie

When he didn't love me? 
The girl can swear to take revenge for several reasons ${ }^{5}$. One reason is that the boy has another girl, as in Johan Perez d'Avoin 7, where in the fiinda she threatens vengeance (with a taunt of social superiority, implying that their relationship has raised his standing): E, pois vos eu tornar qual vos achei, / pesar mh á en, mais pero vingar m' $e i$ ( «And once I turn you back into what you were, that will upset me, but I will take revenge»). In another cantiga the boy's sin is merely that he is leaving despite the girl's wishes.

FERNAN FERNANDEZ COGOMINHO - 1.1-12

Amig', e non vos nembrades

de mi e torto fazedes,

mais nunca per mi creades

se mui cedo non veedes

ca sodes mal conselhado

de mi sair de mandado.

Non dades agora nada

por mi e, pois vos partirdes

daqui, mais mui ben vingada

serei de vós quando virdes,

ca sodes mal conselhado

de mi sair de mandado.

Friend, you don't think of me,

And you do me wrong,

But never believe me again

If you don't very quickly see

That you are ill advised

To disobey me.

Now you don't care at all

About me, and since you're going away

From here, I'll really get back

At you when you come again,

For you are ill advised

To disobey me.

5 On vingar / vengar and vinga (substantive) in the cantigas d'amigo, see the complete list in Cohen (1996: 49). For the reasons why girls threaten revenge and the form their vengeance takes, see Cohen (2012: 72-76, 80-82). 
In another poem where the boy is leaving, the girl's revenge will be not to talk with him when he returns.

ROI FERNANDIZ - 3

Id' é meu amigo daqui

e non me quis ante veer,

e Deus mi tolha parecer

e quanto de ben á en mi, se el ven e m' eu non vingar

quand' el quiser migo falar.

E cuida s' el que lhi querrei, por esto que m' el fez, melhor, mais log' el seja o senhor e eu sua, que non seerei, se el ven e m' eu non vingar quand' el quiser migo falar.

Que viss' eu que non dava ren el por mi, non se m' espediu quando se da terra partiu, mais logo me lh' eu quera ben, se el ven e m' eu non vingar quand' el quiser migo falar.

E veerá mui ben o meu amigo quant' el ora fez, a que lhi salrrá esta vez, ca en seu poder seja eu, se el ven e m' eu non vingar quand' el quiser migo falar.

Ca lhi non querrei ascuitar

nulha ren do que m' el rogar.

My boyfriend has gone away from here And didn't want to see me first, And may God take away my good looks And all the joy there is in me If he comes and I don't take revenge When he wants to talk with me. 
And he thinks I'll love him more

For this thing he did to me,

But may he be at once the lord

And I his girl, which I will not be,

If he comes and I don't take revenge

When he wants to talk with me.

So that I'd see he didn't care

At all about me, he didn't say goodbye

When he went away from this land,

But may I love him at once

If he comes and I don't take revenge

When he wants to talk with me.

And my boyfriend will see

Very well what he did right now,

How it will turn out for him,

For may I be in his power

If he comes and I don't take revenge

When he wants to talk with me.

'Cause I won't want to listen to

A single thing he wants to ask.

So there is considerable evidence that the girl in Nuno Treez 2 calls her boyfriend a false traitor and swears to take revenge against him. We cannot know why she would call him fals'e traedor, but other texts suggests that one of several reasons would be sufficient: 1) he has been unfaithful; 2) he has failed to show up for a tryst, thereby breaking an oath; 3 ) he has not come back, although he promised to; 4) he is leaving.

Here Treez 3 can be invoked, since in that poem the girl says she has been asking San Clemenço to bring the boy back to her. If, then, we read Treez 2 and 3 together, it would seem plausible that the boy's «treason» could be that he has not yet returned. And although we cannot tell what form her revenge will take, if we can judge by other poems where a girl vows vengeance, she may merely mean that she will refuse to talk with him when he finally appears.

We can also contextualize Treez 2 and 3 by reading his two other cantigas d'amigo. In Treez 1 the girl tells us she went to the chapel of San Clemenço but the boy did not appear (v. 9 E fui eu fazer oraçon a San Clemenç'e non vos vi). In Treez 4 a messenger brings the girl the news (which delights her) that the boy is coming: Agora verrá aqui voss'amigo. 
Further support is to be found in a parody of precisely the kind of oath that the girl swears in Treez 2: not to sleep.

JOHAN GARCIA DE GUILHADE - 14

Chus mi tarda, mhas donas, meu amigo

que el migo posera,

e crece m' end' ũa coita tan fera

que non ei o cor migo,

e jurei ja que, atá que o visse,

que nunca ren dormisse.

Quand' el ouv' a fazer a romaria, pos m' un dia talhado

que vẽesse, $<\mathrm{e}>$ non ven, mal pecado;

oje se compr' o dia,

e jurei ja que, atá que o visse, que nunca ren dormisse.

Aquel dia que foi de mi partido

el mi jurou chorando

que verria, e pos mi praz' e quando;

ja o praz' é saido,

e jurei ja que, atá que o visse,

que nunca ren dormisse.

My boyfriend is tarrying, my ladies,

More than he'd promised

And a sorrow grows in me, so strong

That I lose heart,

And I swore that, until I saw him,

I wouldn't sleep at all.

When he had to make the pilgrimage

He set a day with me

That he'd come, and he hasn't — oh the shame!

Today was the day;

And I swore that, until I saw him,

I wouldn't sleep at all. 
The day that he went away from me

He swore to me, crying,

That he'd come, and he set a day and time,

And now the time is up,

And I swore that, until I saw him,

I wouldn't sleep at all.

The girl in this text swore she would not sleep until the boy came back, as he had promised (vv. 8-9 and 14-15). And yet the day has come, the time is up, and he has not returned. The joke is that she has committed herself to a presumably long stretch of self-imposed sleep deprivation which she is not likely to survive.

In somma: There are no other examples in this genre where a girl calls a saint falso or traedor or swears vengeance against him or her. But there is ample evidence that a girl, for a variety of reasons, calls her boyfriend a liar and a traitor and vows to take revenge against him. And to ice the cake, Guilhade 14 mocks the kind of oath (not to sleep) that the girl swears in our text. So we may conclude that in Nuno Treez 2 the girl, addressing San Clemenço, calls her boyfriend a false traitor and swears she will not sleep until she gets back at him. This is the only reading that the pragmatic grammar of this genre allows.

\section{BIBLIOGRAPHY}

$B=$ Biblioteca Nacional de Portugal (Lisbon), cod. 10991.

$V=$ Biblioteca Apostolica Vaticana (Rome), cod. lat. 4803.

$C A=$ Michä̈lis de VAsconcelos, Carolina (1904): Cancioneiro da Ajuda. Halle: Max Niemeyer, 2 vols.

Cohen, Rip (1996): «Dança Jurídica», Colóquio-Letras 142, pp. 5-49.

Cohen, Rip (2003): 500 Cantigas d'Amigo. Porto: Campo das Letras.

Cohen, Rip (2010): «Pragmatics and Textual Criticism in the Cantigas d'Amigo», in M. Arbor Aldea \& A. F. Guiadanes (eds.): Estudos de edición crítica e lírica galego-portuguesa. Santiago de Compostela: Universidade de Santiago de Compostela ( = Verba, Anuario Galego de Filoloxia, Anexo 67), pp. 25-42.

Conen, Rip (2012): Erotic Angles on the Cantigas d'Amigo (Papers of the Medieval Hispanic Research Seminar, 68). London: Department of Iberian and Latin American Studies, Queen Mary, University of London. 
Cohen, Rip (2014): The Cantigas of Pero Meogo. Washington DC: Virtual Center for the Study of Galician-Portuguese Lyric $<$ https://blogs.commons.georgetown. edu/cantigas/files/2013/05/Cohen-Meogo-NOVISSIMA-EDITIO-371a-rev3-Edition-mjf.pdf $>$.

Couceiro, José Luís (1993): «Nuno Treez», in G. Lanciani \& G. Tavani (coord.): Dicionário da Literatura Medieval Galega e Portuguesa. Lisboa: Caminho, pp. 484-485.

Nunes, José JoAquim (1926-1928): Cantigas d'amigo dos trovadores galegoportugueses. Coimbra: Imprensa da Universidade, 3 vols. 